\title{
PENINGKATAN MOTIVASI BELAJAR DAN PRESTASI HASIL BELAJAR FISIKA PESERTA DIDIK MELALUI MODEL PEMBELAJARAN GROUP INVESTIGATION
}

\author{
Eko Mulyadi ${ }^{1}$, Warnoto ${ }^{2}$ \\ 1,2 SMK Negeri 3 Yogyakarta \\ 1echoy_m@yahoo.com, ${ }^{2}$ wwarnoto@yahoo.com
}

\begin{abstract}
Abstrak: Penelitian Tindakan Kelas ini bertujuan untuk meningkatkan motivasi belajar dan prestasi hasil belajar Fisika peserta didik di kelas XTL2 SMK Negeri 3 Yogyakarta melalui model Group Investigation (GI) dalam pembelajaran Fisika Kompetensi Fluida dan Gelombang. Penelitian ini dilaksanakan dua siklus, setiap siklus terdiri dari 2-3 pertemuan, setiap pertemuan dengan alokasi waktu 3 jam pelajaran. Setiap siklus meliputi empat langkah, yaitu perencanaan, tindakan, pengamatan dan refleksi. Hasil penelitian menunjukkan bahwa peningkatan motivasi belajar pada siklus I sebesar $75 \%$, pada siklus II sebesar $90,63 \%$ terjadi peningkatan $16,63 \%$. Peningkatan prestasi hasil belajar rata-rata pra-siklus 31,09 , siklus I rata-rata 65,60 tuntas $28,13 \%$, pada siklus II rata-rata 86,28 , tuntas $68,75 \%$. Penelitian ini 2 siklus, karena pada siklus II, motivasi belajar lebih dari $80 \%$, dan prestasi hasil belajar lebih dari $60 \%$, penerapan model GI perlunya diterapkan dan diteruskan dalam pembelajaran karena adanya peningkatan baik motivasi belajar maupun prestasi hasil belajar. Kata kunci: Group Investigation, motivasi belajar, Prestasi hasil belajar

\section{IMPROVING LEARNING MOTIVATION AND STUDENT PHYSICS LEARNING OUTCOMES THROUGH THE GROUP INVESTIGATION LEARNING MODEL}

\begin{abstract}
This Classroom Action Research aims to increase learning motivation and student achievement in Physics learning in XTL2 grade SMK Negeri 3 Yogyakarta through the Group Investigation (GI) model in learning Fluid and Wave Competence Physics. This study was conducted in two cycles, each cycle consisting of 2-3 meetings, each meeting with an allocation of 3 lesson hours. Each cycle includes four steps, namely planning, action, observation and reflection. The results showed that the increase in motivation to learn in the first cycle by $75 \%$, in the second cycle of $90.63 \%$ an increase of $16.63 \%$. Improvement of the average pre-cycle learning outcomes of 31.09 , the first cycle of an average of 65.60 completed $28.13 \%$, in the second cycle an average of 86.28 , $68.75 \%$ complete. This research is 2 cycles, because in cycle II, learning motivation is more than $80 \%$, and learning achievement achievement is more than 60\%, the application of the GI model needs to be applied and continued in learning due to an increase in both learning motivation and learning achievement.
\end{abstract}

Keywords:GI, learning motivation, achievement of learning outcomes

\section{PENDAHULUAN}

Satuan Pendidikan merupakan lembaga pendidikan formal dituntut untuk melaksanakan proses belajar mengajar yang baik dan maksimal sehingga dapat menghasilkan generasi muda yang memiliki kompetensi keahlian serta berfikir dan dapat berkomunikasi dengan baik. Kompetensi keahlian serta berfikir maksudnya memiliki wawasan dan pengetahuan yang luas tentang bidang yang ditekuninya, kemampuan berfikir krtis, kreatif. Sedangkan berkomunikasi artinya peserta didik memiliki kemampuan bekerjasama, dan menyampaikan gagasan idenya.

Pendidik sebagai fasilitator dalam proses pendidikan yang akan membekali generasi mendatang dapat memberikan inspirasi kepada peserta didik. Dia bukan lagi sebagai obyek belajar, tetapi diposisikan sebagai subyek belajar. Peserta didik berangkat dari rumah sudah membawa bekal pengetahuan, yang bisa didapat dari berbagai sumber google, youtube, WhatsApp, Instagram dll. Sehingga peran pendidikan sangat diperlukan oleh peserta didik dalam mengembangkan minat, bakat dan potensinya.

Selanjutnya perubahan paradigma belajar dari peserta didik yang semula bekerja secara individual kemudian beralih secara kelompok dalam memecahkan suatu masalah, masalah dapat dipecahkan dengan base learning yang dapat diselesaikan secara berkelompok dan berkolaborasi dalam mencapai tujuan belajar. Tugas pendidik memberikan arahan, belajar 
atau pelayanan yang menyenangkan bagi peserta didik.

Pengamatan yang dilakukan Peneliti di SMK N 3 Yogyakarta bahwa peserta didik kurang antusias dan pasif dalam mengikuti proses belajar mengajar dengan metode klasikal, masih banyaknya peserta didik yang senang bermain game online dari gadget, mencuri waktu membaca WhatsApp-an, menyelesaikan tugas belum optimal masih ketergantungan dengan temannya, malu bertanya, malu mengemukakan pendapat, tidak menghargai temannya saat temannya presentasi, ulangan cenderung kerjasama dengan temannya, tidak percaya diri.

Berdasarkan data Penilaian Akhir Semester Gasal. Rerata nilai Fisika peserta didik kelas XTL2 SMK N 3 Yogyakarta sebagai berikut:

Tabel 1. Nilai Fisika Penilaian Akhir Semester Gasal Peserta Didik Kelas XTL2 SMK N 3

Yogyakarta Tahun Pelajaran 2019/2020.

\begin{tabular}{ccc}
\hline Kelas & Rerata & KKM \\
\hline XTL2 & 31,09 & 75 \\
XTP1 & 36,36 & 75 \\
XKJ & 55,71 & 75 \\
XAV2 & 45,00 & 75 \\
\hline
\end{tabular}

Berdasarkan data tersebut maka prestasi hasil belajar Fisika Kelas XTL2 paling rendah dan perlu ditingkatkan. Sebagai upaya meningkatkan motivasi belajar dan prestasi hasil belajar peserta didik, perlu dikembangkan model pembelajaran yang tepat, pendidik menyampaikan konsep dalam pembelajaran yang memberikan kesempatan bagi peserta didik untuk bertukar pendapat, bekerjasama dengan teman, berinteraksi dengan pendidik dan merespon pemikiran peserta didik sehingga peserta didik dapat lebih memahami materi yang diajarkan.

Dengan memperhatikan keadaan di atas maka diperlukan metode dan model pembelajaran yang akan dapat meningkatkan motivasi belajar, mengaktifkan peserta didik serta memacu inovasi pembelajaran Fisika di SMK. Oleh sebab itu dipilih Model Group Investigation dalam pembelajaran Fisika untuk meningkatkan motivasi belajar dan prestasi hasil belajar Fisika peserta didik Kelas XTL2 di SMK N 3 Yogyakarta Tahun Pelajaran 2019/2020. Model Group Investigation dipilih untuk menyelesaikan masalah di kelas XTL2 karena kecenderungan peserta didik yang pasif, perlu ditingkatkan motivasi belajar dan prestasi hasil belajarnya.
Terdapat tiga konsep utama dalam metode Group Investigation, yaitu: penelitian atau inquiry, pengetahuan atau knowledge, dan dinamika kelompok atau the dynamic of the learning group, (Udin S. Winaputra, 2001:75). Penelitian di sini adalah proses dinamika siswa memberikan respon terhadap masalah dan memecahkan masalah tersebut. Pengetahuan adalah pengalaman belajar yang diperoleh siswa baik secara langsung maupun tidak langsung. Sedangkan dinamika kelompok menunjukkan suasana yang menggambarkan sekelompok saling berinteraksi yang melibatkan berbagai gagasan dan pendapat serta saling share pengalaman dengan proses saling beragumentasi.

Berdasarkan latar belakang dan identifikasi masalah maka perumusan masalah dalam penelitian ini adalah :1) Bagaimana proses pembelajaran Fisika dengan model Group Investigation untuk meningkatkan motivasi belajar peserta didik kelas XTL2 di SMK N 3 Yogyakarta? 2)Bagaimana proses pembelajaran Fisika dengan model Group Investigation untuk meningkatkan prestasi hasil belajar Fisika peserta didik kelas XTL2 di SMK N 3 Yogyakarta?

Penelitian ini dilakukan dengan tujuan untuk: 1) Meningkatkan motivasi belajar peserta didik kelas XTL2 di SMK N 3 Yogyakarta melalui penerapan Model Group Investigation dalam pembelajaran Fisika. 2) Meningkatkan prestasi hasil belajar peserta didik kelas XTL2 di SMK N 3 Yogyakarta dengan penerapan Model Group Investigation dalam pembelajaran Fisika

Belajar adalah suatu kinerja atau suatu proses untuk memperoleh pengetahuan, meningkatkan keterampilan, memperbaiki perilaku, sikap, dan mengokohkan kepribadian. Dalam konteks menjadi tahu atau proses memperoleh pengetahuan, menurut pemahaman sains konsvensional, kontak manusia dengan alam diistilahkan dengan pengalaman (experience). Pengalaman itu terjadi berulang kali melahirkan pengetahuan, (knowledge), atau a body of knowledge. Definisi ini merupakan definisi umum dalam pembelajaran sains secara konvensional, dan beranggapan bahwa pengetahuan sudah terserak di alam, tinggal bagaimana siswa atau pembelajar bereksplorasi, menggali, dan menemukan kemudian memunggutnya, untuk memperoleh pengetahuan (Suyono \& Haryanto, 2014:9). 
Menurut UU Sisdiknas No. 20 Tahun 2003, pembelajaran adalah proses interaksi Siswa dengan pendidik dan sumber belajar pada suatu lingkungan belajar. Dalam proses Siswa sebagai subyek belajar, baik Siswa maupun guru sama-sama proses belajar dan pembelajaran.

Fisika adalah ilmu yang mempelajari tentang materi atau zat yang meliputi sifat fisis, komposisi, perubahan, dan energi yang dihasilkannya. Oleh karena itu, perkembangan ilmu pengetahuan dan teknologi yang sangat pesat saat ini tidak lepas dari ilmu Fisika sebagai salah satu ilmu dasar. Ilmu Kedokteran, Teknologi industri, Teknologi manufaktur dan teknologi informasi, misalnya perkembangan pesat dibidang teknologi informasi dan komunikasi saat ini, telepon selular dan satelit tidak lepas dari aplikasi dari pembelajaran Fisika pada materi gelombang elekteromagnetik. Perkembangan teknologi yang sangat pesat ini, harus selaras dengan peningkatan mutu SDM agar arah perkembangan ilmu pengetahuan dan teknologi dapat menuju sasaran yang tepat. Kami sebagai guru, perhatian yang seksama dalam peningkatan mutu SDM., khususnya dalam melihat permasalahan-permasalahan dan perkembangan di dalam proses pembelajaran, Siswa maupun bahan ajar yang di ajarkan (Suparman, 2007).

Pembelajaran Fisika adalah proses interaksi antara peserta didik, pendidik dan media pembelajaran pada lingkungan alam, kompetensi untuk penelitian ini tentang Fluida, Gelombang. Penyampaian Fluida dan Gelombang ini karena konseptual dan faktual, maka penting untuk penerapan model pembelajaran Group Investigation, agar peserta didik mendapat pengalaman empiris tentang Fluida dan Gelombang.

Motivasi dalam belajar adalah faktor yang penting karena hal tersebut merupakan keadaan yang mendorong siswa untuk belajar. Motivasi dalam belajar adalah bagaimana cara mengatur agar motivasi dapat ditingkatkan. Demikian pula dalam kegiatan belajar mengajar seorang anak didik akan berhasil jika mempunyai motivasi untuk belajar. Nasution (1995:73) mengatakan motivasi adalah "segala daya yang mendorong seseorang untuk melakukan sesuatu." Sedangkan Sardiman (1992:77) mengatakan bahwa "motivasi adalah menggerakkan siswa untuk melakukan sesuatu atau ingin melakukan sesuatu.
Indikator Motivasi Menurut Hamzah (2016:23) diklasifikasikan menjadi: 1) Adanya hasrat dan keinginan berhasil, 2) Adanya dorongan dan kebutuhan dalam belajar, 3) adanya harapan dan cita-cita masa depan, 4) adanya pernghargaan dalam belajar, 5) adanya kegiatan yang menarik dalam belajar, 6) adanya lingkungan belajar yang kondusif, sehingga memungkinkan seorang siswa dapat belajar dengan baik.

Indikator motivasi dapat ditunjukkan dengan gejala-gejala yang dapat diamati berdasarkan pada indikator motivasi belajar. Indikator motivasi belajar dan aspek-aspek penampakannya adalah sebagai berikut:

Tabel 2. Indikator motivasi belajar dan aspekaspek penampakannya (Bekti M, Ide Guru, 2019:3).

\begin{tabular}{ll}
\hline \multicolumn{1}{c}{$\begin{array}{c}\text { Indikator } \\
\text { Motivasi Belajar }\end{array}$} & \multicolumn{1}{c}{ Aspek yang dapat diamati } \\
\hline $\begin{array}{l}\text { Adanya hasrat } \\
\text { dan keinginan } \\
\text { berhasil }\end{array}$ & $\begin{array}{l}\text { Tertarik untuk menyelesaikan } \\
\text { soal-soal pelajaran }\end{array}$ \\
\hline $\begin{array}{l}\text { Adanya } \\
\text { dorongan dan } \\
\text { kebutuhan } \\
\text { dalam belajar }\end{array}$ & $\begin{array}{l}\text { Senang dengan aktifitas } \\
\text { belajar }\end{array}$ \\
\hline $\begin{array}{l}\text { Adanya harapan } \\
\text { dan cita-cita } \\
\text { masa depan }\end{array}$ & $\begin{array}{l}\text { Memperhatikan penjelasan } \\
\text { guru, ingin mempelajari, } \\
\text { ingin tahu }\end{array}$ \\
\hline $\begin{array}{l}\text { Adanya } \\
\text { penghargaan } \\
\text { dalam belajar }\end{array}$ & $\begin{array}{l}\text { Menyelesaikan tugas tepat } \\
\text { waktu }\end{array}$ \\
\hline $\begin{array}{l}\text { Adanya } \\
\text { kegiatan yang } \\
\text { menarik dalam } \\
\text { belajar }\end{array}$ & Bertanya pada guru bila ada \\
\hline $\begin{array}{l}\text { Adanya } \\
\text { lingkungan } \\
\text { belajar yang } \\
\text { kondusif }\end{array}$ & $\begin{array}{l}\text { Mengajukan/menanggapi } \\
\text { pertanyaan }\end{array}$ \\
\hline
\end{tabular}

Dalam penelitian ini ke-6 indikator di atas dijadikan questioner motivasi belajar yang akan diisi oleh peserta didik.

Menurut W.J.S Poerwadarrninta (1987: 767) menyatakan bahwa prestasi belajar adalah hasil yang dicapai sebaik - baiknya menurut kemampuan anak pada waktu tertentu terhadap hal - hal yang dikerjakan atau dilakukan.

Hasil belajar sering digunakan sebagai ukuran untuk mengetahui seberapa jauh seseorang menguasai bahan yang diajarkan (Purwanto, 2016:44), bisa juga diartikan segenap ranah psikologis yang berubah sebagai akibat pengalaman dan proses belajar siswa, 
baik secara kuantitatif maupun secara kualitatif (Syah, 1995:150).

Jadi prestasi belajar adalah hasil belajar yang telah dicapai menurut kemampuan yang tidak dimiliki dan ditandai dengan perkembangan serta perubahan tingkah laku pada diri seseorang yang diperlukan dari belajar dengan waktu tertentu, prestasi belajar ini dapat dinyatakan dalam bentuk nilai dan hasil tes atau ujian. Prestasi hasil belajar pelajaran Fisika yang akan diukur adalah kemampuan siswa dalam memahami konsep, perhitungan dan aplikasi standar kompetensi Fluida dan gelombang

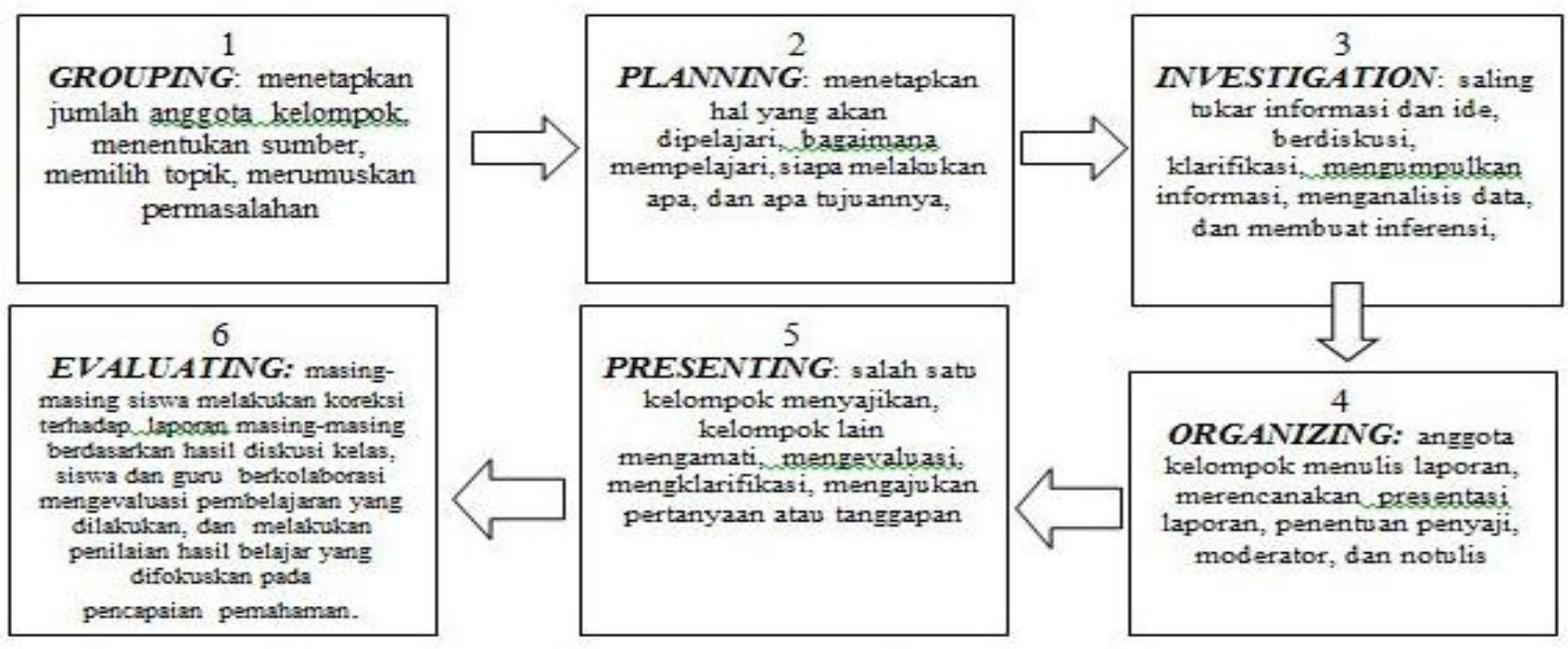

Gambar 1, Langkah-langkah GI (Modifikasi dari Slavin, 1995)

Model pembelajaran group investigation berawal dari perspektif filosofis terhadap konsep belajar. Untuk dapat belajar, orang harus memiliki pasangan atau teman. Pada tahun 1916, John Dewey menulis sebuah buku Democracy and Education (Arends, 1998). Dalam buku itu, Dewey menggagas konsep pendidikan bahwa kelas seharusnya merupakan cermin masyarakat dan berfungsi sebagai laboratorium untuk belajar tentang kehidupan nyata. Pemikiran Dewey yang utama tentang pendidikan (Jacob et al, 1996) adalah: (1) siswa hendaknya aktif: learning by doing; (2) belajar hendaknya didasari motivasi intrinsik; (3) pengetahuan berkembang, tidak bersifat tetap; (4) kegiatan belajar hendaknya sesuai dengan kebutuhan dan minat siswa; (5) pendidikan harus mencakup kegiatan belajar dengan prinsip saling memahami dan saling menghormati satu sama lain: prosedur demokratis sangat penting; (6) kegiatan belajar hendaknya berhubungan dengan dunia nyata.

Gagasan Dewey akhirnya diwujudkan dalam model group investigation yang kemudian dikembangkan oleh Herbert Thelen. Thelen menyatakan bahwa kelas hendaknya merupakan miniatur demokrasi yang bertujuan mengkaji masalah-masalah sosial antarpribadi (Arends, 1998). Slavin (1995) mengatakan pembelajaran model group investigation memiliki enam langkah (Gambar 1).
Hipotesis Tindakan: "Model Group Investigation dapat meningkatkan motivasi belajar dan prestasi hasil belajar peserta didik".

\section{METODE PENELITIAN}

Penelitian Tindakan Kelas ini dilaksanakan di SMK 3 Yogyakarta, Jl. R.W Monginsidi No. 2 Yogyakarta.

Setting penelitian dilakukan di dalam kelas di ruang 73 dengan langkah-langkah Group Investigation: (1) grouping, (2) planning (3) investigation, (4) organizing (5) dan (6) evaluating. Setiap kelompok diberi materi yang berbeda, dari materi tersebut didiskusikan secara kelompok, peserta didik menjabarkan dalam kertas A3 meliputi Pegertian, Ilustrasi gambar, rumus dan keterangan, contoh soal dan penyelesaiannya, kesimpulan, kemudian peserta didik mempresentasikan dan mengevaluasi hasilnya. Penelitian tindakan kelas ini akan dilaksanakan di kelas XTL2 SMK Negeri 3 Yogyakarta semester genap tahun pelajaran 2019/2020, dengan jumlah peserta didik yang menjadi subjek penelitian adalah 32 peserta didik.

Penelitian ini menggunakan rancangan penelitian tindakan kelas (Classroom action research) dengan mengikuti model yang dikembangkan oleh Kemmis dan Mc Taggart (1990:14), yang kemudian oleh Suharsimi 
Arikunto (2006:16) dan Yoko Rimy (2008:12) dijabarkan sebagai berikut:

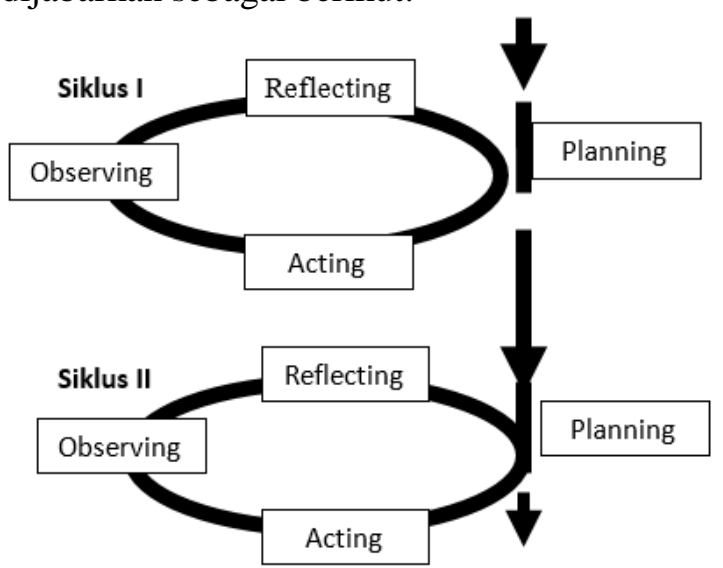

Gambar 2. Siklus dalam penelitian CAR model Kemmis dan Targart

Rencana tindakan dilakukan dalam dua siklus, setiap siklusnya terdiri dari 2-3 tatap muka, sekali tatap muka 3x 45 menit. Setiap siklus mencakup 4 tahapan, yaitu: Perencanaan, pelaksanaan, pengamatan dan refleksi. Kegiatan perencanaan dilakukan pada tiap pertemuan dalam satu siklus.

Pada siklus I: (1) Perencanaan: a. menyiapkan bahan ajar, silabus, RPP, Kertas A3, spidol warna, naskah soal pos tes b. menyiapkan form angket motivasi belajar dan, tentang penerapan GI sebagai refleksi. (2) Pelaksanaan pada Pertemuan 1: a. Pendidik mengkomunikasikan tujuan pembelajaran atau kompetensi Fluida yang harus dicapai dan rambu-rambu tugas yang akan dilakukan. b. Peserta didik dibagi ke dalam 9 Kelompok, setiap kelompok membahas materi yang berbeda, c. Pendidik membagi materi kepada setiap kelompok berdasarkan hasil Penilaian Akhir Tahun semester gasal, d. Peserta didik mengerjakan materi yang diberikan dengan rambu-rambu: ada definisi atau pengertian, membuat ilustrasi gambar, menuliskan rumus dan keterangan, membuat contoh soal dan penyelsaiannya dan membuat kesimpulan, e. Setelah selesai hasil kelompok difoto dan diuapload kegrup WA Kelas.

Pada Pertemuan 2 dan 3: a. Peserta didik secara kelompok menyiapkan hasil diskusi kelompok baik berupa hardcopy maupun softcopy untuk dipersentasikan didepan kelas. b. Pendidik mengarahkan tata cara presetansi dan aturan mainnya, c. Peserta didik mempresentasikan hasil diskusi yang telah dibuat, d. Diadakan tanya jawab, e. Kolaborator mencatat motivasi peserta didik sesuai format, f. Pendidik sebagai pengarah jika ada permasalahan yang tidak bisa dijawab oleh kelompok yang presentasi, g. Setelah semua kelompok presentasi kemudian diadakan pos tes dan pengisian angket motivasi belajar.

Kegiatan (3) pengamatan dilakukan guru peneliti dan kolaborator terhadap kinerja siswa dalam diskusi kelompok, proses penyelesaian masalah, diskusi kelas (presentasi) dan guru peneliti mengoreksi pos tes kemudian hasilnya dimasukkan ke dalam daftar nilai (prestasi) belajar Siswa.

Kegiatan (4) Refleksi Diakhir siklus I peserta didik diberi angket tentang pembelajaran dengan model Group Investigation dalam Pembelajaran Fisika sebagai refleksi untuk mendiskusikan temuantemuan dalam pembelajaran. Refleksi dilakukan juga oleh peneliti bersama kolaborator.

Dan seterusnya, siklus II mirip dengan siklus I, tetapi dengan materi Fisika berbeda. Untuk siklus II materi gelombang yang meliputi getaran, periode, frekuensi, getaran pada bandul, getaran pada pegas, persamaan getaran, jenis dan besaran gelombang, persamaan gelombang, gelombang berdiri dan bunyi.

\section{Teknik Pengumpulan Data dan Analisis Data}

Pegumpulan data dilakukan dengan instrumen angket motivasi dengan google form yang telah dibuat. Untuk instrumen motivasi belajar Hamzah (2016:23), motivasi diklasifikasikan menjadi: 1) Adanya hasrat dan keinginan berhasil, 2) Adanya dorongan dan kebutuhan dalam belajar, 3) adanya harapan dan cita-cita masa depan, 4) adanya pernghargaan dalam belajar, 5) adanya kegiatan yang menarik dalam belajar, 6) adanya lingkungan belajar yang kondusif.

Hasil angket dianalisis dengan rentang dan kategori: 1,00-1,74 Sangat kurang; 1,75-2,49 Kurang; 2,50-3,24 Baik; 3,25-4,00 Sangat Baik. Hasil rata-rata motivasi belajar diolah dengan Rumus (Furqon, 1999:36),

$$
x=\frac{\Sigma x i}{N}
$$

Dengan keterangan:

$\mathrm{x}=$ rata-rata motivasi belajar; $\Sigma \mathrm{xi}=$ data kei-I; $\mathrm{N}=$ Jumlah data

Data motivasi belajar menggunakan skala Lingkert 1,2,3,4, terdiri dari 6 butir aspek pertanyaan, skor minimal 6, maksimal 24 , 
dibagi menjadi tiga rentang data, yakni rendah, sedang dan tinggi. Rumus pembagian rentang:

Rendah $\mathrm{X} \leq \mathrm{M}-\mathrm{SD}$

Sedang $\mathrm{M}-\mathrm{SD} \leq \mathrm{X}<\mathrm{M}+\mathrm{SD}$

Tinggi $\mathrm{M}+\mathrm{SD} \leq \mathrm{X}$

$\mathrm{M}=(\mathrm{xmin}+\mathrm{xmax}) / 2$

$\mathrm{R}=\mathrm{X} \max -\mathrm{X} \min$

$\mathrm{SD}=\mathrm{R} / 6$;

kurva normal terdiri atas 6 standar deviasi

Keterangan:

$\mathrm{M}=$ Mean (rata-rata)

$\mathrm{SD}=$ Standard Deviasi

Tabel 3. Rentang Motivasi belajar peserta didik

\begin{tabular}{cc}
\hline Kategori & Rentang \\
\hline Rendah & $6-11$ \\
Sedang & $12-17$ \\
Tinggi & $18-24$ \\
\hline
\end{tabular}

Untuk menghitung persentase peserta didik yang memiliki motivasi belajar kategori tinggi, digunakan rumus:

Persentase $=$ $\frac{\text { jml peserta didik motivasi tinggi }}{\text { jml seluruh siswa }} \times 100 \%$

Prestasi hasil belajar yang diukur adalah hasil pos tes. Dalam penelitian pos tes materi Fluida pada siklus I dan Materi gelombang pada Siklus II. Serta dokumentasi berupa rekapitulasi pos tes. Hasil nilai prestasi belajar gabungan antara hasil diskusi dan hasil pos tes kemudian dirata-rata. Bukti foto-foto kegiatan dilampirkan.

Prestasi hasil belajar menuliskan nilai minimum, nilai maksimum, rata-rata, dan ketuntasan. Rumus menghitung ketuntasan:

Ketuntasan $=$

jml peserta didik mendapat

$\frac{\text { nilai di atas sama dengan KKM }}{\text { jml seluruh siswa }} x 100 \%$

Teknik analisis data dilakukan dengan teknik deskriptif kualitatif dan kuantitatif, yakni dengan mendeskripsikan data mengenai motivasi belajar peserta didik selama proses pembelajaran baik dalam proses, deskripsi kuantitatif dengan mendeskripsikan motivasi dari hasil angket peserta didik mengenai penerapan Model Group Investigation diakhir proses dan prestasi hasil belajar peserta didik dari nilai hasil diskusi dan pos tes baik pada siklus I, II dan seterusnya.

\section{Indikator Keberhasilan}

Indikator keberhasilan dalam Penelitian Tindakan Kelas ini adalah: (1) Motivasi belajar peserta didik meningkat jika $\geq 80 \%$ dari peserta didik memiliki skor motivasi belajar kategori tinggi. (2) Prestasi Hasil belajar peserta didik meningkat jika $\geq 60 \%$ dari seluruh peserta didik telah mencapai kreteria ketuntasan minimal (KKM).

\section{HASIL DAN PEMBAHASAN}

Kelas XTL2 terdiri dari 32 peserta didik putra, di dalam proses pembelajaran Fisika, kurang antusias karena lelah setelah pelajaran pesjaskes olah raga, main game online, WhatsApp-an pada saat pendidik menjelaskan, kurang aktif dan cenderung pasif, diminta bertanya tidak ada yang bertanya, tidak ada yang berargumentasi, tidak ada yang berani mengkritisi tentang pembelajaran, masih nuansa segan dan tidak percaya diri.

Pembelajaran Fisika jam ke 3-5 (08.3011.00 WIB), Kelas XTL2 pelajaran Fisika setelah pelajaran olah raga maka kondisi para peserta didik terlihat lelah, lesu, kurang antusias, tidak bergairah dalam pembelajaran, oleh karena itu perlu dilakukan pembelajaran yang dapat mengaktifkan, menggerakan para peserta didik, dipilih model Group Investigation (GI), karena di dalam GI ada 6 langkah : (1) grouping, (2) planning (3) investigation, (4) organizing (5) presenting dan (6) evaluating , ada membagi materi dengan peserta didik aktif mendiskusikannya, serta mempresentasikannya.

Tabel 4. Hasil ulangan umum semester ganjil mata pelajaran Fisika kelas XTL2 Tahun Pelajaran 2019/2020

\begin{tabular}{cc}
\hline Prestasi Belajar & $\begin{array}{c}\text { Hasil Ulangan Umum } \\
\text { Fisika }\end{array}$ \\
\hline Nilai Minimum & 15 \\
Nilai Maksimum & 47,5 \\
Ketuntasan & $0(0 \%)$ \\
Nilai Rata-rata & 31,09 \\
Daya Serap & $0 \%$ \\
\hline
\end{tabular}

Tabel 4. menunjukkan hasil ulangan umum semester gasal tahun 2019/2020, nilai tertinggi 47,50 , nilai terendah 15 dengan ratarata 31,09, dengan ketuntasan 0\%, di atas KKM 75 , tidak ada, sedangkan daya serap $0 \%$ prestasi hasil belajar Fisika sangat rendah dan belum optimal.

\section{Deskripsi Siklus I}

1. Perencanaan Tindakan

Di dalam perencanaan tindakan pendidik menyiapkan instrument Rencana Pelaksanaan 
Pembelajaran, dengan model Group Investigation (GI), tiga kali pertemuan, pertemuan pertama : guru membagi kelompok berdasarkan hasil tes Ulangan Umum kelas X, secara heterogen dari sisi nilai, menentukan tujuan pembelajaran, model pembelajaran GI, guru membagi materi tentang Fluida menjadi 9 kelompok : Tekanan hidrostatis, Hukum Pascal, Hukum Archimedes, Tegangan Permukaan, Kapilaritas, Debit Fluida, Persamaan Kontinuitas, dan Asas Benoulli. Materi-materi ini diselesaikan secara kelompok melalui diskusi kelompok dengan memuat: Pengertian, Ilustrasi Gambar, Rumus dan Keterangan, Contoh Soal dan penyelesaian, dan Kesimpulan. Hasil diskusi kelompok dipresentasikan di kelas, diadakan tanya jawab, guru menyiapkan perangkat penilaian.

Pertemuan kedua: peserta didik secara berkelompok mempresentasikan hasil diskusi kelompoknya, pendidik menilai motivasi peserta didik melalui diskusi dan presentasi kelas, menilai hasil diskusi kelompok: pengertian, ilustrasi gambar, rumus dan keterangan, soal dan penyelesaian dan kesimpulan. Pertemuan ketiga: penguatan, refleksi dan pos tes, koreksi pos tes.

Guru menyiapkan instrument RPP, form motivasi, naskah soal pos tes, form monitoring dan prestasi hasil belajar Fisika peserta didik dari pra siklus, siklus I, siklus II dst.

\section{Pelaksanaan Tindakan}

Sesuai dengan RPP pendidik di awal pertemuan menjelaskan tujuan dan langkahlangkah pembelajaran dengan model GI mulai (1) grouping: menetapkan jumlah anggota kelompok, menentukan sumber, memilih topik, merumuskan permasalahan, (2) planning: menetapkan hal yang akan dipelajari, bagaimana mempelajari, siapa melakukan apa, dan apa tujuannya, (3) investigation: saling tukar informasi dan ide, berdiskusi, klarifikasi, mengumpulkan informasi, menganalisis data, dan membuat inferensi, (4) organizing: anggota kelompok menulis laporan, merencanakan presentasi laporan, penentuan penyaji, moderator, dan notulis, (5) presenting: salah satu kelompok menyajikan, kelompok lain mengamati, mengevaluasi, mengklarifikasi, mengajukan pertanyaan atau tanggapan, dan (6) evaluating: masing-masing peserta didik melakukan koreksi terhadap laporan masingmasing berdasarkan hasil diskusi kelas, peserta didik dan pendidik berkolaborasi mengevaluasi pembelajaran yang dilakukan, dan melakukan penilaian hasil belajar yang difokuskan pada pencapaian pemahaman.

Pertemuan kedua: seluruh kelompok mempresentasikan hasil yang telah dibuat secara berkelompok, pendidik melakukan penilaian dengan indikator kelompok menuliskan pengertian, ilustrasi gambar, rumus dan kesimpulan, contoh soal dan pembahasan dan kesimpulan. pendidik memberikan penilaian hasil diskusi kelompok, presentasi dan tanya jawab.

Pertemuan ketiga guru mengadakan penguatan dan dilakukan pos tes, kemudian guru menilai hasil pos tes.

\section{Hasil Pengamatan}

a. Hasil Kinerja pada Siklus I

Hasil Pengamatan Ada 6 aspek motivasi belajar peserta didik (1) Adanya hasrat dan keinginan berhasil, 2) Adanya dorongan dan kebutuhan dalam belajar, 3) adanya harapan dan cita-cita masa depan, 4) adanya pernghargaan dalam belajar, 5) adanya kegiatan yang menarik dalam belajar, 6) adanya lingkungan belajar yang kondusif, sehingga memungkinkan seorang peserta didik dapat belajar dengan baik.

Tabel 5. Motivasi peserta didik per aspek pada siklus I

\begin{tabular}{clcl}
\hline No & \multicolumn{1}{c}{ Motivasi } & $\begin{array}{c}\text { Skor } \\
\text { Siklus I }\end{array}$ & Kategori \\
\hline 1 & $\begin{array}{l}\text { Saya punya hasrat } \\
\text { dan ingin berhasil }\end{array}$ & 3.85 & $\begin{array}{l}\text { Sangat } \\
\text { Baik }\end{array}$ \\
\hline 2 & $\begin{array}{l}\text { Saya terdorong dan } \\
\text { butuh untuk belajar }\end{array}$ & 3.23 & Baik \\
\hline 3 & $\begin{array}{l}\text { Saya punya harapan } \\
\text { dan cita-cita masa } \\
\text { depan }\end{array}$ & 3.77 & $\begin{array}{l}\text { Sangat } \\
\text { Baik }\end{array}$ \\
\hline 4 & $\begin{array}{l}\text { Saya menginginkan } \\
\text { penghargaan dalam } \\
\text { belajar }\end{array}$ & 3.15 & Baik \\
\hline 5 & $\begin{array}{l}\text { Saya tertarik dalam } \\
\text { kegiatan belajar }\end{array}$ & 3.00 & Baik \\
\hline 6 & $\begin{array}{l}\text { Saya ingin adanya } \\
\text { lingkungan belajar } \\
\text { yang kondusif }\end{array}$ & 3.31 & $\begin{array}{l}\text { Sangat } \\
\text { Baik }\end{array}$ \\
\hline $\begin{array}{l}\text { Rata-rata motivasi } \\
\text { Peserta Didik }\end{array}$ & 3,38 & $\begin{array}{l}\text { Sangat } \\
\text { Baik }\end{array}$ \\
\hline
\end{tabular}

Dari Tabel 5 menunjukkan motivasi peserta didik rata-rata 3,38 , kategori sangat baik, menurut rentang: 1,00-1,74 Sangat kurang, 1,75-2,49 Kurang, 2,50-3,24 Baik, 3,25-4,00 Sangat Baik. 
Motivasi belajar peserta didik kelas XTL2 pada siklus I.

Tabel 6. Motivasi belajar peserta didik Siklus I

\begin{tabular}{cccc}
$\begin{array}{c}\text { Rentang } \\
\text { skor } \\
\text { Angket }\end{array}$ & $\begin{array}{c}\text { Kategori } \\
\text { Motivasi }\end{array}$ & $\begin{array}{c}\text { Frekuensi } \\
\text { Peserta } \\
\text { didik } \\
\text { Siklus I }\end{array}$ & $\begin{array}{c}\text { Prosesntase } \\
(\%)\end{array}$ \\
\hline $6-11$ & Rendah & 6 & 18,75 \\
$12-17$ & Sedang & 2 & 6,25 \\
$18-24$ & Tinggi & 24 & 75,00 \\
\hline
\end{tabular}

Dari Tabel 6 menunjukkan bahwa 18,75\% peserta didik motivasi belajarnya masih rendah, $6,25 \%$ sedang dan $75 \%$ motivasi belajar tinggi.

b. Prestasi Hasil Belajar pada siklus I

Tabel 7. Prestasi Hasil Belajar Fisika pada Siklus I

\begin{tabular}{lcc}
\hline PRESTASI HASIL & \multicolumn{2}{c}{ SIKLUS 1 } \\
\cline { 2 - 3 } BELAJAR & Pra Siklus & Pos tes \\
\hline Nilai Minimum & 15 & 20 \\
Nilai Maksimum & 47,5 & 90 \\
Ketuntasan & $0(0 \%)$ & $9(28,13 \%)$ \\
Nilai Rata-rata & 31,09 & 65,60 \\
Penguatan (gain) & \multicolumn{2}{c}{34,51} \\
\hline
\end{tabular}

Dari Tabel 7 menunjukkan peningkatan nilai rata-rata dari 31,09 menjadi 65,60 dan peningkatan ketuntasan peserta didik dari $0 \%$ menjadi 28,13 \%. Hal ini menunjukkan penerapan model GI dapat meningkatkan prestasi hasil belajar pembelajaran Fisika materi Fluida.

\section{Refleksi pada siklus I}

Penentuan kelompok pada siklus I, ditentukan guru berdasarkan hasil ulangan umum bersama atau penilaian akhir semester (PAS), hasil refleksi dengan angket peserta didik kelas XTL2 bahwa pembentukan kelompok didasarkan pada hasil pos tes terakhir. Penguatan materi dilaksanakan oleh pendidik setelah peserta didik presentasi secara berkelompok, atau penguatan pada saat selesai presentasi.

Saat suatu kelompok presentasi, para peserta didik belum memperhatikan masih ada yang berbicara dengan temannya, bermain game online, WhatsApp-an, bahkan tidur lelah alasan habis olahraga. Saat suatu kelompok selesai presentasi dengan menawarkan ada pertanyaan: "siapa yang mau tanya?", maka peserta didik cenderung lama mengajukan pertanyaan, atau kurang percaya diri, masih kategori malu untuk bertanya.
Hasil kerja kelompok: menuliskan pengertian, peserta didik masih total menyalin dari referensi, belum memberikan ringkasan dengan bahasa sendiri yang mudah dipahami, ilustrasi gambar, ada yang belum diberi keterangan bagian-bagian pada gambar, rumus dan keterangannya diberi besaran tetapi tidak ditulis satuannya, contoh soal dan pembahasan, sudah mengikuti pakemnya Fisika, diketahui, ditanya dan jawab, kesimpulan sudah sesuai dengan tujuan yang diharapkan.

Pada siklus I diperoleh motivasi belajar tinggi tercapai $75 \%$, sehingga belum mencapai $80 \%$ dari keberhasilan, sedangkan hasil kentuntasan belajar diperoleh $28,13 \%$ yang ditaget $60 \%$, belum tercapai, sehingga perlunya ditingkatkan. Strategi yang perlu ditingkatkan pada Siklus II adalah penguatan dari guru.

\section{Deskripsi Siklus II}

1. Perencanaan Tindakan

Dari hasil refleksi siklus I, maka perencanaan yang dilakukan adalah membagi kelompok berdasarkan hasil pos tes Fluida, dibagi ke dalam 8 kelompok membahas materi gelombang: 1) getaran, frekuensi, periode, 2) Getaran pada bandul, 3) Getaran pada pegas, 4) Persamaan getaran, 5) jenis-jenis dan besaran gelombang, 6) Persamaan gelombang, 7) Gelombang berdiri, dan 8) Bunyi.

Menyiapkan RPP gelombang, angket motivasi, naskah soal pos tes, form rekapitulasi motivasi dan prestasi hasil belajar Fisika peserta didik, angket refleksi dan lembar jawab pos tes.

\section{Pelaksanaan Tindakan}

Pada pertemuan pertama siklus II, pendidik memberi penjelasan tentang tujuan pembelajaran gelombang, pembagian materi untuk kelompok yang sudah terbentuk berdasarkan hasil pos tes Fluida, pendidik membagikan materi sesuai kelompok, peserta didik mendiskusikan materi, hasil diskusi kelompok dipresentasikan dan dievaluasi, hasil diskusi meliputi: pengertian materi, ilustrasi gambar, rumus dan keterangan, contoh soal dan pembahasan, kesimpulan.

Pertemuan kedua, 8 kelompok mempresentasikan hasil diskusinya, pendidik menilai motivasi kesesuaian dengan angket motivasi. Pertemuan ketiga, pendidik memberikan penguatan materi yang telah dipresentasikan, pendidik melakukan refleksi dengan membagikan angket tentang senang, 
paham dan keterkaitan dengan kompetensi keahlian. pendidik mencatat setiap peserta didik yang bertanya, argumentasi, memberi saran, mengkritisi dan menjawab pertanyaan baik dari pendidik maupun dari temannya.

Setelah dilakukan penguatan diadakan pos tes, pendidik memeriksa hasil pekerjaan pos tes jawaban peserta didik, pendidik mengolah data dengan menuliskan nilai minimum, maksimum, rata-rata, ketuntasan, penguatan (gain).

3. Hasil Pengamatan Siklus II

a. Hasil Motivasi Siklus II

Rekapitulasi hasil motivasi (Tabel 8).

Tabel 8. Motivasi peserta didik per aspek pada siklus II

\begin{tabular}{clcl}
\hline No & \multicolumn{1}{c}{ Motivasi } & $\begin{array}{c}\text { Skor } \\
\text { Siklus II }\end{array}$ & $\begin{array}{c}\text { Kateg } \\
\text { ori }\end{array}$ \\
\hline 1 & $\begin{array}{l}\text { Saya punya hasrat } \\
\text { dan ingin berhasil }\end{array}$ & 3.61 & $\begin{array}{l}\text { Sangat } \\
\text { Baik }\end{array}$ \\
\hline 2 & $\begin{array}{l}\text { Saya terdorong dan } \\
\text { butuh untuk belajar }\end{array}$ & 3.19 & Baik \\
\hline 3 & $\begin{array}{l}\text { Saya punya } \\
\text { harapan dan cita- } \\
\text { cita masa depan }\end{array}$ & 3.84 & $\begin{array}{l}\text { Sangat } \\
\text { Baik }\end{array}$ \\
\hline 4 & $\begin{array}{l}\text { Saya menginginkan } \\
\text { penghargaan dalam } \\
\text { belajar }\end{array}$ & 3.26 & $\begin{array}{l}\text { Sangat } \\
\text { Baik }\end{array}$ \\
\hline 5 & $\begin{array}{l}\text { Saya tertarik dalam } \\
\text { kegiatan belajar }\end{array}$ & 3.13 & Baik \\
\hline 6 & $\begin{array}{l}\text { Saya ingin adanya } \\
\text { lingkungan belajar } \\
\text { yang kondusif }\end{array}$ & 3.52 & $\begin{array}{l}\text { Sangat } \\
\text { Baik }\end{array}$ \\
\hline $\begin{array}{l}\text { Rata-rata Motivasi } \\
\text { Peserta Didik }\end{array}$ & 3,42 & $\begin{array}{l}\text { Sangat } \\
\text { Baik }\end{array}$ \\
\hline
\end{tabular}

Tabel 8 menunjukkan rata-rata motivasi belajar peserta didik per aspek 3,42, ada peningkatan motivasi pada siklus I sebesar 3,38 , terjadi penguatan sebesar $0,04(4 \%)$.

Motivasi belajar peserta didik kelas XTL2 pada siklus II

Tabel 9. Motivasi belajar peserta didik Siklus II

\begin{tabular}{clll}
\hline Rentang & Kategori & \multicolumn{3}{c}{ Frekuensi Peserta didik } \\
\cline { 3 - 4 } skor & Motivasi & \multicolumn{1}{c}{ Siklus I } & \multicolumn{1}{c}{ Siklus II } \\
\hline $6-11$ & Rendah & $6(18,75 \%)$ & $1(3,13 \%)$ \\
$12-17$ & Sedang & $2(6,25 \%)$ & $2(6,25 \%)$ \\
$18-24$ & Tinggi & $24(75,00 \%)$ & $29(90,63 \%)$ \\
\hline
\end{tabular}

Dari Tabel 9 menunjukkan bahwa motivasi belajar tinggi dari siklus I ke Siklus II mengalami kenaikan 5 peserta didik (naik 15,63\%). Pada siklus I jumlah peserta didik yang memiliki motivasi belajar tinggi sebanyak 24 peserta didik atau sebesar $75 \%$, pada siklus II jumlah peserta didik yang memiliki motivasi belajar tinggi sebanyak 29 peserta didik atau sebesar 90,63\%.

Dari tabel menunjukkan bahwa persentase peserta didik yang memiliki motivasi belajar tinggi pada siklus I belum mencapai $80 \%$, maka indikator keberhasilan penelitian yang berupa peningkatan motivasi belajar belum tercapai. Pada siklus II persentase peserta didik yang memiliki motivasi belajar tinggi sudah diatas $80 \%$ dari seluruh peserta didik yang dijadikan subjek penelitian yang berupa adanya peningkatan motivasi belajar peserta didik telah tercapai pada siklus II.

b. Hasil Prestasi pada siklus II

Hasil pos tes tentang gelombang direkapitulasi maka diperoleh Tabel 10.

Tabel 10. Prestasi Belajar Fisika pada Siklus II

\begin{tabular}{ccc}
\hline PRESTASI & \multicolumn{2}{c}{ SIKLUS II } \\
HASIL & Pos tes & Pos tes \\
BELAJAR & Siklus I & \\
\hline Nilai Minimum & 20 & 73 \\
Nilai Maksimum & 90 & 97 \\
Ketuntasan & $9(28,13 \%)$ & $22(68,75 \%)$ \\
Nilai Rata-rata & 65,60 & 86,28 \\
Penguatan (Gain) & \multicolumn{2}{c}{20,68} \\
\hline
\end{tabular}

Tabel 10 menunjukkan hasil pos tes siklus I, nilai minimum 20, nilai maksimum 90, ketuntasan $28,13 \%$, nilai rata-rata diperoleh 65,60 , sedangkan hasil pos tes siklus II, nilai minimum 73 , dan nilai maksimum 97, disebabkan waktu penguatan jauh lebih besar dibandingkan siklus I, ketuntasan $28,13 \%$, nilai rata-rata dari 65,60 menjadi 86,28 , juga ada kenaikan, sedangkan penguatan 20,68.

\section{Refleksi}

Peningkatan motivasi hanya $4 \%$, tidak terlalu signifikan hal ini disebabkan karena pembelajaran Fisika setelah mata pelajaran Penjaskes Olahraga, peserta didik mengalami kelelahan setelah olahraga, sedangkan harus banyak berfikir secara kognitif. Namun pada diskusi kelompok tidak ada yang mengantuk atau tidur.

Berbeda pada saat presentasi suatu kelompok, masih ada peserta didik yang kurang antusias mendengarkan kelompok presentasi, bahkan Tanya jawab juga pertanyaan masih seputar contoh kehidupan sehari-hari, siapa penemu rumus dan teorinya? belum mengarah kepada konten pengembangan dan aplikasi teknologi abad 21 menganut berfikir tingkat 
tinggi, kreatifitas, komunikasi, literasi, dan karakter. Sehingga perlunya penguatan peserta didik baik pada sikap kritis, pengetahuan dan keterampilan sesuai abad 21."

\section{PEMBAHASAN}

1. Pembahasan motivasi siklus I, dan siklus II Rekapitulasi motivasi belajar pada siklus I, dan siklus II ditunjukkan Gambar 3

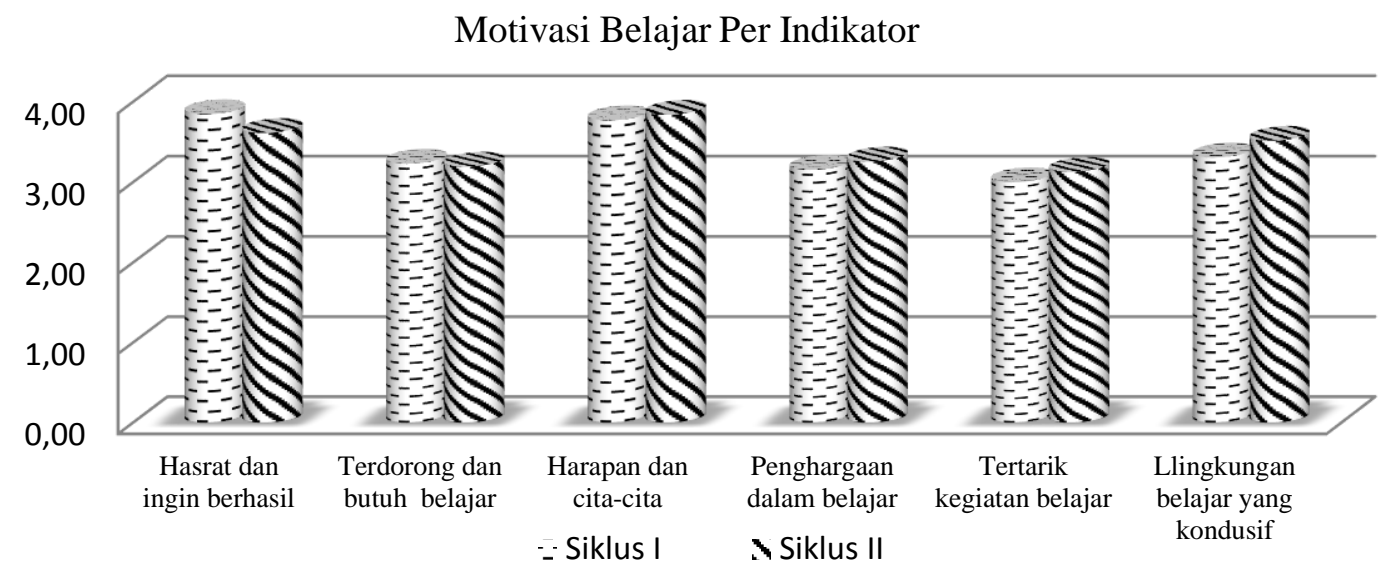

Gambar 3. Grafik motivasi belajar peserta didik per indikator dari siklus I ke siklus II

Gambar 3 menunjukkan motivasi dengan 2 indikator mengalami penurunan dan 4 indikator mengalami kenaikan. Penurunan pada hasrat dan ingin berhasil menurun 0,24, terdorong dan butuh untuk belajar menurun 0,04, tetapi masih kategori sangat baik disebabkan fakta bahwa keinginan untuk berhasil dan butuh belajar tinggi namun fakta tidak sesuai karena fisik kelelahan setelah pelajaran olahraga. Sulit didorong untuk berfikir, perlunya jeda istirahat tidak cukup hanya 10-15 menit, minimal istriharat 30 menit. Sedangkan punya cita-cita dan harapan, inginkan penghargaan dalam belajar, tertarik dalam kegiatan belajar, dan ingin adanya lingkungan belajar yang kondusif mengalami kenaikan. Kenaikan rata-rata motivasi dari siklus I ke siklus II sebesar 0,04.

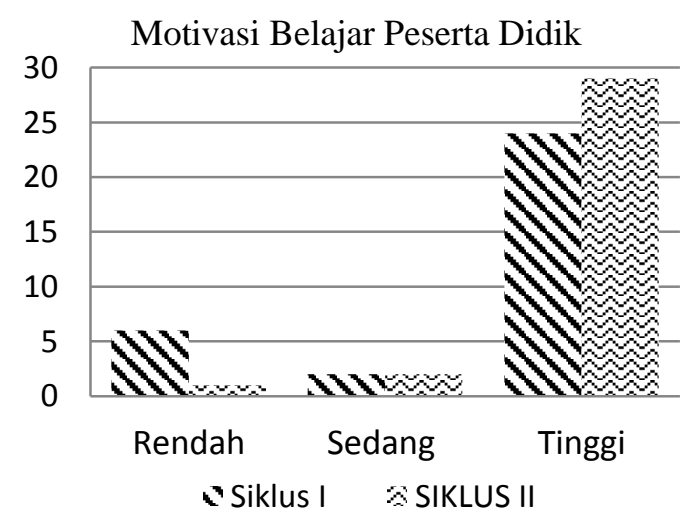

Gambar 4. Grafik peningkatan motivasi peserta didik peserta didik dari Siklus I ke Siklus II

Pada Siklus I motivasi belajar rendah 6, pada siklus II berkurang 5 menjadi 1 peserta didik, sedangkan motivasi belajar sedang tetap, dan motivasi belajar tinggi meningkat 5 orang pada Siklus I berjumlah $24(75 \%)$ peserta didik, sedangkan pada siklus II menjadi 29 orang $(90,63 \%)$.

\section{Pembahasan Prestasi belajar Fisika}

Hasil rekapitulasi pos tes, dari siklus I dan siklus II diperoleh (Gambar 5)

Gambar 5 menunjukkan Nilai rata-rata pra-siklus 31,09, siklus I: 65,60 dan siklus II: 86,28 , sedangkan penguatan (Gain) pra siklus ke siklus 1: 34,51, siklus 2: 20,68.

Peningkatan ini dapat dilihat pada Gambar 5. 


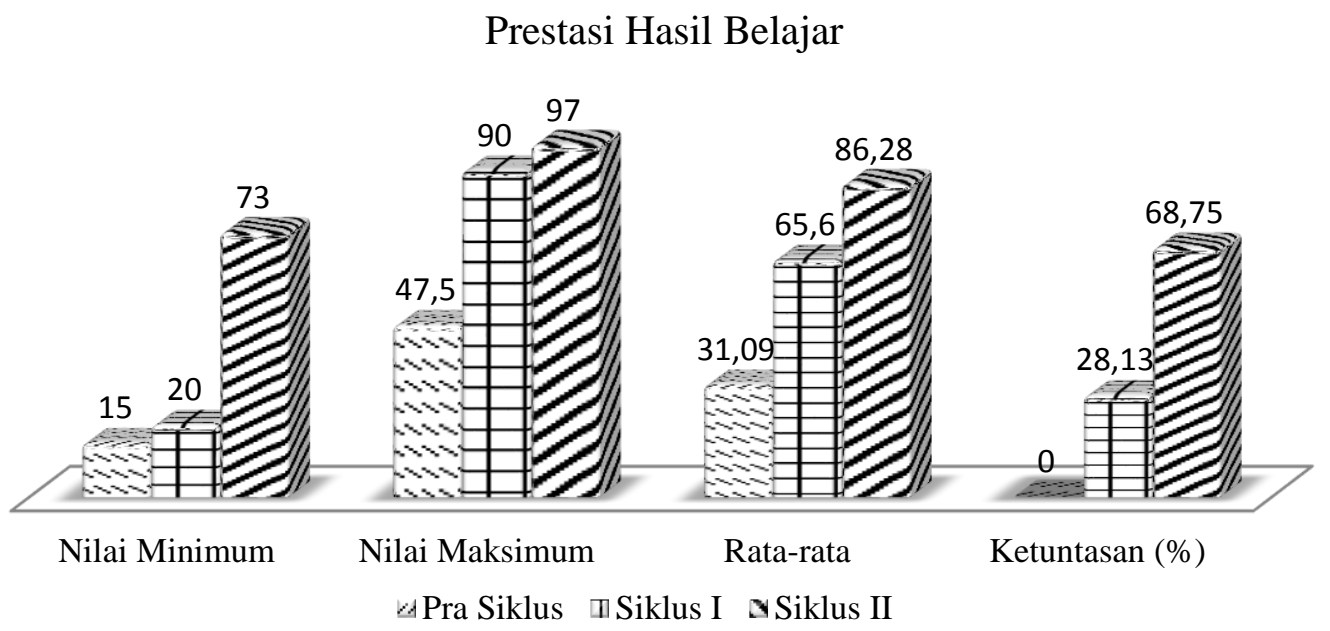

Gambar 5. Peningkatan prestasi belajar Fisika peserta didik

Peningkatan ini terjadi karena semakin hari peserta didik semangat dalam pertemuan, usaha mendiskusikan materi, mengerjakan secara berkelompok lebih enjoy meskipun ada peserta didik yang mengeluh kurang paham, ternyata prestasi hasil belajarnya ada peningkatan, dengan model GI ini dapat meningkatkan hasil prestasi belajar Fisika.

\section{SIMPULAN}

Hasil penelitian dengan model GI, pada siklus I peserta didik yang memiliki motivasi kategori tinggi sebesar 24 atau $75 \%$, pada siklus II peserta didik yang memiliki motivasi kategori tinggi sebesar 29 atau 90,63\%. Model Pembelajaran GI dapat meningkatkan motivasi belajar siswa kelas XTL2.

Dari prestasi hasil belajar Fisika peserta didik pada siklus I terdapat 9 orang mencapai ketuntasan atau sebesar $28,13 \%$, peserta didik yang mencapai KKM, pada siklus II terdapat 22 orang mencapai ketuntasan atau sebesar $68,75 \%$ peserta didik mencapai KKM. Model Pembelajaran GI dapat meningkatkan prestasi hasil belajar Fisika siswa kelas XTL2.

\section{DAFTAR PUSTAKA}

A.M, Sardiman. (1992). Interaksi dan Motivasi Belajar Mengajar, Jakarta: Rajawali Pers

Arends, R.I. (1998). Learning to Teach. New York: MC Grow Hill. Inc.

Arikunto, Suharsimi, dkk. (2006). Penelitian Tindakan Kelas. Jakarta: Bumi Aksara

Furqon. (1999). Statistik Terapan untuk Penelitian. Bandung: Alfabeta.
Mulatsih, Bekti. (2019). Peningkatan Motivasi Belajar dan Hasil Belajar Kimia Peserta Didik Kelas XIMIPA dengan model Pembelajaran Kooperatif STAD. Jurnal Ide Guru: Disdikpora DIY.

Nasution. (1995). Dikdaktik Asas-asas Mengajar. Jakarta: Bumi Aksara.

Permendiknas No. 23 Tahun 2006 tentang Standar Kompetensi Lulusan

Poerwadarminta, WJS. (1987). Kamus umum Bahasa Indonesia. Jakarta: Balai Pustaka.

Rimy, Yoko. (2008). Penelitian Tindakan Kelas sebagai Bentuk Pengembangan Profesi Guru. Yogyakarta: LPMP

Slavin, Robert E (1995). Cooperative Learning Theory, Research and Practice. Massachusett, USA: Allymand \& Bacon

Suparman. (2007). Meningkatkan Kinerja Belajar Dan Hasil Belajar Di Materi Listrik Statis Dengan Pembelajaran Berbasis ICT Pada Kelas XII IPA 3 SMAN 4 Kendari. Kendari: SMAN 4.

Suyono dan Hariyanto. (2014). Belajar dan Pembelajaran. Bandung; Remaja Rosdakarya.

Syah, Muhibbin. (2002). Psikologi Pendidikan. Bandung: Rosda Karya

Udin S. Winaputra. (2001). Model Pembelajaran Inovatif. Jakarta: Universitas Terbuka. Cet. Ke-1. 